\title{
RUBELLA IMMUNITY IN A COHORT OF PREGNANT WOMEN - SEROLOGICAL SURVEY
}

\author{
Milena D. KARCHEVA ${ }^{1 凶}$, Anton P. GEORGIEV ${ }^{2}$, Alexander B. BLAZHEV ${ }^{3}$ \\ ${ }^{1}$ Department of Infectious Diseases, Epidemiology, Parasitology and Tropical Medicine, Medical \\ University-Pleven, Pleven, Bulgaria \\ ${ }^{2}$ Department of Obstetrics and Gynecology, Medical University-Pleven, Pleven, Bulgaria \\ ${ }^{3}$ Department of Biology, Medical University-Pleven, Pleven, Bulgaria
}

Received 24 July 2019, Accepted 05 Oct 2019

https://doi.org/10.31688/ABMU.2019.54.4.06

\section{Abstract}

Introduction. Rubella is a worldwide contagious disease with self-limited symptoms and a generalized rash. Epidemiology of rubella changed after licensing the vaccine in 1969. Children's rubella is a self-limited infection, but when it occurs during pregnancy, there is a risk of severe damage to the fetus.

Objectives. The aim of this study was to determine the immunity against rubella virus in pregnant women in Pleven Region, Bulgaria.

Methods. A cross-sectional study was carried out on pregnant women hospitalized in a Clinic of obstetrics and gynecology, University Hospital-Pleven, Bulgaria. Quantitative determination of specific Immunoglobulin $G(\mathrm{Ig} G)$ antibodies against rubella virus was performed by Enzyme-Like Immunosorbent Assay (ELISA). Data were analyzed using the Microsoft Office Excel 2007 software.

Results. Between January 2018 and December 2018 there were collected and tested to Rubella virus IgG antibody 242 serum samples. Two hundred and four (84.30\%) of them were positive, 29 (11.98\%) were negative and $9(3.72 \%)$ - equivocal. The age of examined

\section{RÉSUMÉ}

Immunité contre le virus de la rubéole chez un groupe de femmes enceintes- étude sérologique

Introduction. La rubéole est une maladie contagieuse à l'échelle mondiale aux symptômes légers et une éruption cutanée généralisée. L'épidémiologie de la rubéole a changé après l'autorisation du vaccin en 1969. La rubéole chez les enfants représente une infection spontanément résoluble, mais lors d'une grossesse le foetus risque d'être gravement atteint.

Objectifs. Le but de cette recherche est d'évaluer l'immunité contre le virus de la rubéole chez les femmes enceintes dans la région de Pleven, Bulgarie.

Méthodes. Une recherche transversale a été conduite incluant des femmes enceintes hospitalisées au Département d'obstétrique-gynécologie de l'Hôpital Universitaire de Pleven, Bulgarie. Une détermination quantitative des anticorps Immunoglobuline $\mathrm{G}(\mathrm{IgG})$ spécifiques contre le virus de la rubéole a été menée à l'aide de la méthode immuno-enzymatique ELISA. Le logiciel Microsoft Office Excel 2007 a été utilisé pour analyser les données. 
women was between 14 and 45 years, average 27, $\operatorname{sd} \pm 6.429$. We found high seropositivity within age group 21-30 years of age. The immunization status of the investigated women shows - unimmunized - 79, selectively immunized with one dose of monovaxin - 58, immunized with combined (measles, mumps, rubella) vaccine one dose -82 , with a double immunization schedule - 23. In each group there were seropositive women.

Conclusions. Data analysis shows that pregnant women have high immunity and a tendency for lower morbidity rates of acute rubella infection.

Keywords: rubella immunity, pregnancy, immunoglobulin $\mathrm{G}$ antibodies.

\section{Abbreviations}

Immunoglobulin $\mathrm{G}$ - IgG

Enzyme-Like Immunosorbent Assay - ELISA

Congenital Rubella Syndrome - CRS

Measles, Mumps, Rubella - MMR

\section{INTRODUCTION}

The importance of rubella infection as a public healthcare problem is determined by teratogenic effect of Rubella virus during pregnancy. Rubella in a pregnant woman can lead to congenital rubella syndrome (CRS) in the infant. The birth defects include heart disease, blindness, deafness and mental retardation. There is a high percentage of spontaneous abortions ${ }^{1}$. All countries that include rubella vaccine in their immunization services should conduct surveillance for CRS and rubella. In the CRS/rubella elimination phase, disease surveillance should focus on detecting cases of CRS/rubella, vaccine coverage rate and serological monitoring of rubella susceptibility. At the present stage, the healthcare practice has a highly effective monovalent and combined (measles, mumps, rubella/varicella) live viral vaccines that provide $90-95 \%$ protection against rubella. Past experience with the use of these vaccines has shown only a temporary reduction of morbidity, rarely until complete discontinuation of the spread of the infection, followed by new outbreaks after a prolonged non-epidemic period. Main cause of the failure in the control of vaccine preventative disease may be inadequate immunization coverage achieved in the implementation of planned programs or mass vaccination campaigns ${ }^{2-3}$.

The immune response of live attenuated rubella vaccine is constructed similarly to immunity after a disease by formation of specific $\operatorname{Ig} G$ antibodies.
Résultats. Dans la période janvier - décembre 2018, 242 échantillons de sérum ont été prélevés et analysés à la recherché des IgM spécifiques de la rubéole. 204 d'eux (84.30\%) étaient positifs, 29 (11.98\%) étaient négatifs et 9 (3.72\%) - équivoques. Les femmes examinées étaient âgées entre 14 et 45 ans, 27 ans en moyenne, $s d \pm 6.429$. Une séroprévalence élevée a été constatée chez le groupe de 21-30 ans. Quant à leur statut de vaccination, 79 des participantes étaient non immunisées, 58 avaient reçu une immunisation sélective d'une dose de monovaxin, 82 étaient immunisées avec une dose de vaccine combiné (rougeole, oreillons, rubéole), 23 avaient fait partie d'un programme d'immunisation de deux doses. Dans chaque groupe il y avait des femmes séropositives.

Conclusions. L'analyse des données indique que les femmes enceintes ont une forte immunité et une tendance à un taux de morbidité plus faible de l'infection rubéolique aiguë.

Mots-clés: rubéole, immunité, grossesse, anticorps Immunoglobuline $\mathrm{G}$.

Immunity after recovery of disease is lasting and life-long. Immunity after vaccination is long-lasting, but there are different opinions in this regard. Important is the type of vaccines and the immunization schedule in different countries. From studies conducted with a three-dose combination vaccine against measles, mumps and rubella, some authors report an increase in the protective titer of antibodies to rubella ${ }^{4}$. To determine the immunological and epidemiological effectiveness of immunizations worldwide seroepidemiological studies were conducted ${ }^{5}$. Studies on the susceptibility of pregnant women to rubella virus show different values in different countries. The importance for value of seroprevalence is the use of vaccine programs ${ }^{6.8}$.

The development of the immunization program in Bulgaria distinguishes three stages:

- Introduction of selective immunization of girls (16-18 years of age) with a monovalent vaccine in 1988-1991 with a low level of immunization range - the vaccine was mainly used in schools of the cities of Sofia, Plovdiv and Varna.

- Scheduled immunization with combined measles-mumps-rubella vaccine of teenagers, starting at 13 months and selective immunization of 12 -year-old girls with a monovalent vaccine. This scheme was included in the country immunization schedule since 1992 and has been in operation since 1993.

- Scheduled immunization with combined measles-mumps-rubella vaccine of all children aged 13 
months and 12 years used to be conducted since 2001.

During the scheduled immunization period, the range of vaccines containing rubella component in both intakes (at 13 months and 12 years) was around and above $90 \%$ of the children. Those born in 1992 and vaccinated with combined MMR in 1993 were given second intakes of that vaccine at 12 years of age, $2004^{9}$.

The obJective of the Study was to determine the immunity against rubella virus in pregnant women in Pleven Region, Bulgaria.

\section{Materials AND MEthods}

A cross-sectional study of the rubella immunity was carried out. The Rubella virus IgG antibodies was determined in human serum. Enzyme-Linked Immunosorbent Assay (ELISA) was applied. NovaLisa Rubella Virus IgG (NovaTec Immunodiagnostica $\mathrm{GmbH}$, Germany) Quantitative determination of specific immunoglobulin $\mathrm{G}(\mathrm{IgG})$ antibodies against rubella virus was performed by ELISA and UVmax kinetic micro plate reader were used. According to supplier instructions antibody levels greater than 15 $\mathrm{IU} / \mathrm{mL}$ were considered as positive, 10-15 - equivocal and lower than $10 \mathrm{IU} / \mathrm{ml}$ as negative. The application of ELISA test has the diagnostic specificity is $>98 \%$ and the diagnostic sensitivity is $>98 \%$.

Data for 242 pregnant women hospitalized in a Clinic of Obstetrics and Gynecology, University Hospital-Pleven, Bulgaria were analyzed. Demographic data of participants (age, education, occupation, location of residency) were collected by interview. Historical data and health status were collected from medical documentation. Women were separated into three groups depending on age: younger than 20 years, between 21 and 30 years and elder than 30 years. After informed consent from every woman, 5 $\mathrm{ml}$ blood was taken and all serum samples were tested in the immunological laboratory in the Department of Biology.

The study was approved by the Ethics Committee for scientific research at Medical University-Pleven.
The statistical analysis was performed by Excel 2007 Microsoft and STATGRAPHICS Centurion. Data were compared by Chi-square test and a $P$ value $<0.05$ was considered statistically significant.

\section{Results}

In total, 242 women were invited to participate in this study. The age of the women was between 14 and 45 years, average age of $27, s d \pm 6.429$. Demographic characteristics of the study group were shown in Table 1. The women surveyed, predominately those living in cities amount to 141 (58.26\%). Regarding the degree

Table 1. Demographic characteristics of the study group.

\begin{tabular}{ccc}
\hline Characteristics & Frequency & Percent \\
\hline Age group & & \\
& & \\
\hline less than 20 years & 44 & 18.2 \\
21 - 30 years & 119 & 49.2 \\
greater than 30 years & 79 & 32.6 \\
\hline Location of residence & & \\
\hline town & 141 & 58.26 \\
village & 101 & 41.74 \\
\hline Education & & \\
\hline primary education & 43 & 17.77 \\
secondary education & 40 & 16.53 \\
high school & 99 & 40.91 \\
tertiary education & 60 & 24.79 \\
\hline Occupation & & \\
\hline unemployed & 95 & 39.3 \\
workers & 40 & 86.5 \\
office workers & 87 & \\
risk groups & 20 & \\
\hline
\end{tabular}

An objective for hospitalization

\begin{tabular}{ccc}
\hline giving birth & 63 & 26.0 \\
\hline premature birth & 69 & 28.5 \\
\hline threatening abortion & 29 & 12.0 \\
\hline imminent abortion & 39 & 16.1 \\
\hline miscarriage & 13 & 5.4 \\
\hline others & 29 & 12.0 \\
\hline
\end{tabular}

* working in kinder units and hospitals

Table 2. Seroprevalence in the study group depending on age groups.

\begin{tabular}{ccccc}
\hline Age group & $\begin{array}{c}\text { Frequency } \\
(\%)\end{array}$ & $\begin{array}{c}\text { Positive } \\
\text { N (\%) }\end{array}$ & $\begin{array}{c}\text { Negative } \\
\text { (\%) }\end{array}$ & $\begin{array}{c}\text { Equivocal } \\
\text { (\%) }\end{array}$ \\
\hline less than 20 years & $44(18.2)$ & $33(75)$ & $8(18.18)$ & $3(6.82)$ \\
$21-30$ years & $119(49.2)$ & $107(89.92)$ & $10(8.40)$ & $2(1.68)$ \\
greater than 30 years & $79(32.6)$ & $64(81.01)$ & $11(13.92)$ & $4(5.07)$ \\
\hline Total & 242 & 204 & 29 & 9 \\
\hline
\end{tabular}




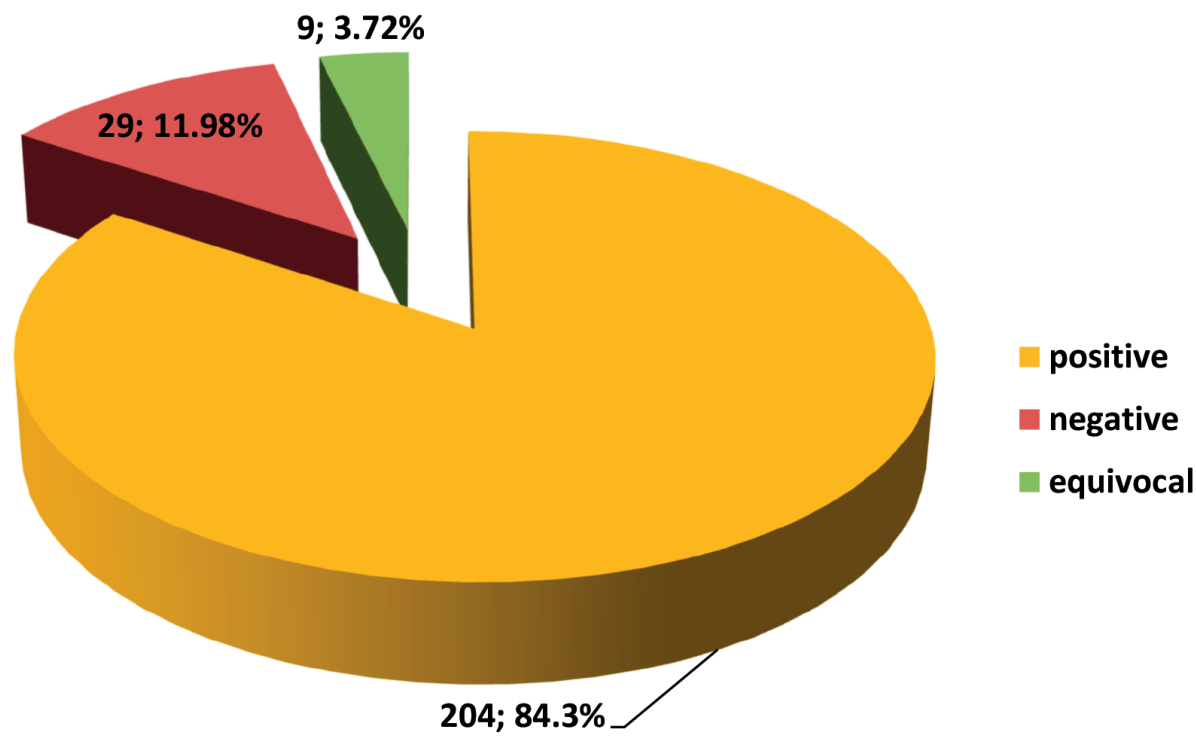

Figure 1. Prevalence of Rubella virus IgG antibody in the study group

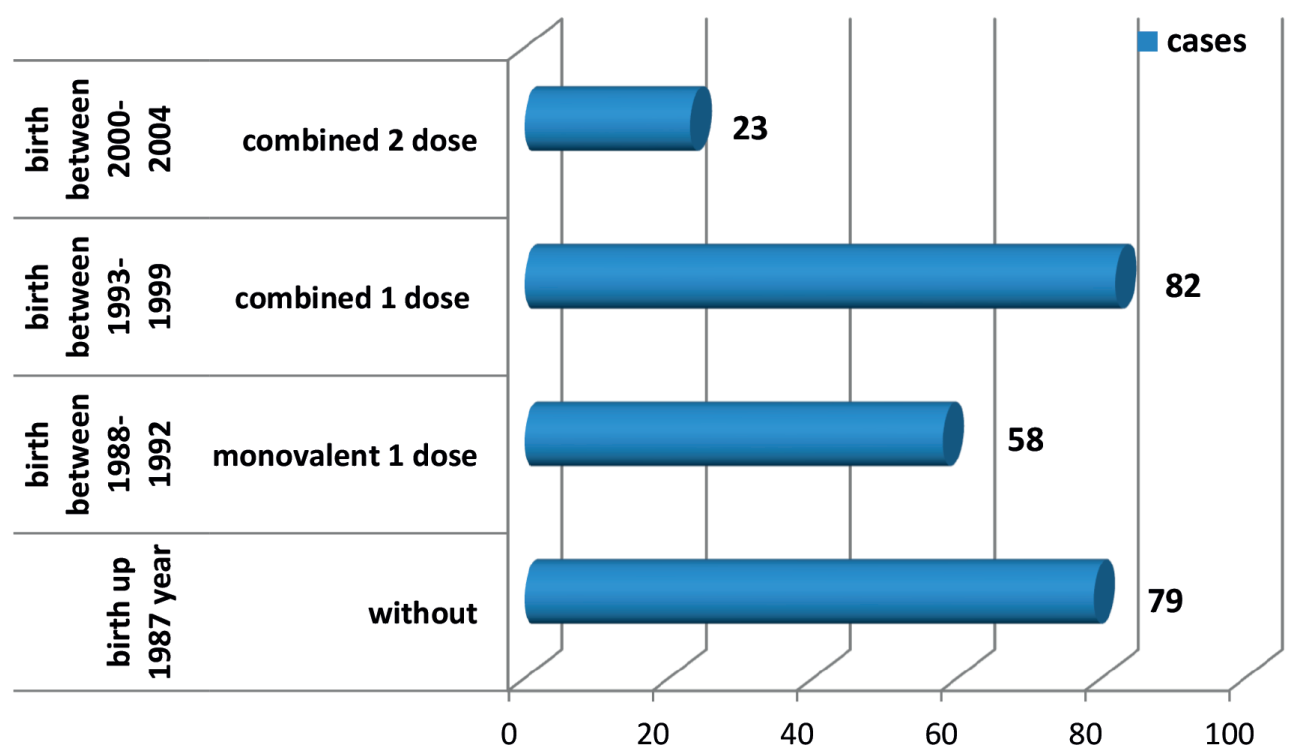

Figure 2. Immunization status of the study group

of education, women with high school education were predominating - 99 (40.91\%). Depending on occupation predominating unemployed women amount to 95 (39.3\%). Twenty (8.3\%) women have professional risk of rubella infection. The reasons established for hospitalization in the clinic were delivery, abortion, others.

Between January 2018 and December 2018 were collected and tested to Rubella virus IgG antibodies 242 serum samples. The serological results of the study are presented in Figure 1 and showed a high level of seropositivity - 204 (84.30\%) of them were positive.
The seroprevalence depending on age groups is shown in Table 2. We found high seropositivity within age group 21-30. A statistically significant difference was found between the group less than 20 years and that between $21-30$ years $\left(\chi^{2}\right.$ test $=9.8 ; P$ value $<0.05)$. Between the second and third groups the differences are not statistically significant ( $P$ value $>0.05$ ).

Depending on their vaccination status, women are divided into four groups shown in Figure 2. Women with mono-vaccine and those without immunization in childhood were predominating. In each of 
the four groups, seropositive women were prevailing: without vaccine (81\%), with mono-vaccine $(91.38 \%)$, with combined vaccine 1 dose $(84.15 \%)$, combined vaccine 2 doses (78.26\%).

\section{Discussion}

In the Global Strategic Plan (2012-2020), the elimination of measles and rubella is set as a key objective to be achieved in 5 of the WHO regions by 2020. In accordance with this plan, a National Program for elimination of measles and rubella (2019-2022) was implemented in Bulgaria. One of the activities to control and survey rubella is to establish immune status after vaccination or illness by detecting protective $\operatorname{IgG}$ antibodies. In his study of 157,763 pregnant women residing in Alberta between 2009 and 2012, Florence Lai (2015) found out the declining level of vaccine-induced antibodies in the population. ${ }^{10}$

In our study, a high level of seropositivity of rubella $\operatorname{IgG}$ antibody is to be seen among pregnant women. We found the highest level of seropositivity in women of 21-30 years of age. These are women born between 1988 and 1997. Immunizations were performed with a monovalent vaccine for some of them and with a combined vaccine for the others. The second dose was administered with combined vaccine at the age of 12 years according to the immunization schedule of Bulgaria. We assume that high seropositivity is due to a two-fold immunization scheme, leading to a decrease in rubella morbidity in the country. Many countries first selectively vaccinated adolescent females, thus creating a cohort of immunized women of childbearing age. Since the introduction of a combined measles, mumps and rubella (MMR) vaccine, many countries have introduced childhood immunization programs for rubel$\mathrm{la}^{3}$. To assess the effectiveness of immunization programs against rubella, the surveillance of Congenital Rubella Syndrome (CRS) was introduced. Its primary goal is the rapid detection and isolation of rubella infected children up to 1 year of age. In this regard, the assessment of immunity to rubella virus in pregnant women is of particular importance - medical, social, economic. High percentages $(84.30 \%)$ of seropositive pregnant women reduce the risk of infection during pregnancy. For 29 (11.98\%) of the women surveyed, there is a risk of infection and therefore a risk for the fetus. In the context of our study, seronegative women are a risk group and should be a subject to immunization. It is necessary to strengthen and improve the system of epidemiological and laboratory surveillance of rubella, to increase the public awareness of the vaccine and the risks of illness for the unvaccinated ${ }^{11}$.

A large number of serological studies has been carried out to determine seroprevalence of rubella infection. Screening of serum samples for rubella IgG antibodies showed that between $80 \%-90 \%$ samples were positive and indicate an immune status12-16. Mirambo $\mathrm{M}$ et al, in a systematic review, report that the seroprevalence of $\operatorname{IgG}$ rubella antibodies in Africa is high but with a substantial number of women of childbearing age being susceptible to rubella infection. Some seroepidemiological surveys from countries in Asia have reported that a substantial number of women reach childbearing age without acquiring natural immunity to rubella, making them more susceptible to infection ${ }^{17-18}$. In Europe, routine immunization has changed the epidemiology of rubella - increased seroprevalence of IgG antibodies and decreased morbidity. Nonetheless, all studies showed that some women of child-bearing age may be susceptible to rubella. Bulgaria is a country with high rate susceptibility in comparison with other European countries ${ }^{12,19-20}$.

\section{Conclusion}

Serological monitoring of rubella susceptibility in women attending Obstetrics and Gynecology clinic can be used to monitor the performance of rubella immunization services. If serological screening is conducted, arrangements should be made to provide postpartum rubella vaccination to women found to be seronegative ${ }^{21}$.

\section{Compliance with Ethics Requirements:}

„The authors declare no conflict of interest regarding this article"

"The authors declare that all the procedures and experiments of this study respect the ethical standards in the Helsinki Declaration of 1975, as revised in 2008(5), as well as the national law. Informed consent was obtained from all the patients included in the study"

"This study was carried out on a scientific research project $N^{\circ} 1 / 2018$ funded by the Medical University-Pleven, Pleven, Bulgaria."

\section{References}

1. Mirambo M, Majigo M, Aboud S, et al. Serological makers of rubella infection in Africa in the pre vaccination era: a systematic review. BMC Res Notes 2015; 8:716.

2. WHO Library Cataloguing-in-Publication Data: Global measles and rubella strategic plan: 2012-2020. 
3. Seppälä EM, López-Perea N, Torres de Mier MV, Echevarría JE, Fernández-García A, Masa-Calles J. Last cases of rubella and congenital rubella syndrome in Spain, 1997-2016: The success of a vaccination program. Vaccine 2019; 37: 169-175.

4. McLean HQ, Fiebelkorn AP, Ogee-Nwankwo A, et al. Rubella virus neutralizing antibody response after a third dose of measles-mumps-rubella vaccine in young adults. Vaccine 2018; 36:5732-5737.

5. Su Q, Ma C, Wen N, et al. Epidemiological profile and progress toward rubella elimination in China. 10 years after nationwide introduction of rubella vaccine. Vaccine 2018;36:2079-2085.

6. Moura AA, Goncalves de Mello MJ, Correia JB. Serological statuses of pregnant women in an urban Brazilian population before and after the 2008 rubella immunization campaign. Vaccine 2016; 34:445-450.

7. Vilajeliu A, García-Basteiro AL, Valencia S, et al. Rubella susceptibility in pregnant women and results of a postpartum immunization strategy in Catalonia, Spain. Vaccine 2015; 33:1767-1772.

8. Shih CT, Chang YC, Wang HL, Lin CC. Comparing the rubella seronegativity in pregnant women who received one dose of rubella vaccine at different ages in Taiwan. Vaccine 2016; 34:4787-4791.

9. National Program for eliminating measles and rubella 2019-2022. (in Bulgarian) https://www.mh.government.bg/ media/filer_public/2015/04/17/plan-eliminatsiya-morbi1i-rubeola-2005-2010.pdf

10. Lai FY, Dover DC, Lee B, et al. Determining rubella immunity in pregnant Alberta women2009-2012. Vaccine 2015; 33:635-641.

11. Hanaoka M, Hisano M, Watanabe N, et al. Changes in the prevalence of the measles, rubella, varicella-zoster, and mumps virus antibody titers in Japanese pregnant women. Vaccine 2013; 31(19): 2343-2347.
12. Nardone A, Tischer A, Andrews N, et al. Comparison of rubella seroepidemiology in 17 countries: progress towards international disease control targets. Bulletin of the World Health Organization 2008;86(2):118-125.

13. Gilbert N, Rotondo J, Shapiro J, et al. Seroprevalence of rubella antibodies and determinants of susceptibility to rubella in a cohort of pregnant women in Canada, 2008-2011. Vaccine 2017; 35: 3050-3055.

14. Gündem N, Kalem F. Seroprevalence of rubella antibodies among Turkish and foreign women in Turkey. Southeast Asian J Trop Med Public Health 2017;48(1):65-72.

15. Gupta A, Jain P, Jain A. Sero-prevalence of rubella virus antibodies in pregnant women in the vicinity of Lucknow, Uttar Pradesh. Archives of Medicine 2015;7(3:7):1-3.

16. Byrne L, Brant L, Reynolds C, Ramsay M. Seroprevalence of low rubella IgG antibody levels among antenatal women in England tested by NHS Blood and Transplant: 2004-2009. Is rubella susceptibility increasing? Vaccine 2012; 30:161-167.

17. Mirambo M, Majigo M, Aboud S, et al. Serological makers of rubella infection in Africa in the pre vaccination era: a systematic review. BMC Res Notes 2015; 8:716.

18. Thayyil J, Kuniyil V, Moorkotha, et al. Prevalence of rubella-specific IgG antibodies in unimmunized young female population. J Family Med Prim Care 2016;5(3):658-662.

19. Poethko-Müller C, Mankertz A. Seroprevalence of measles-, mumps- and rubella-specific IgG antibodies in German children and adolescents and predictors for seronegativity. PLoS One 2012;7(8): e42867.

20. Pebody R, Edmunds W, Spaendonck M, et al. The seroepidemiology of rubella in western Europe. Epidemiol Infect 2000;125:347-357.

21. Picone O, Bouthry E, Bejaoui-Olhmannd Y, et al. Determination of rubella virus-specific humoral and cell-mediated immunity in pregnant women with negative or equivocal rubella-specific IgG in routine screening. Journal of Clinical Virology 2019;112:27-33. 